\title{
TEMPORAL PATTERNS OF WORDS WITH AND WITHOUT SUFFIXES IN SPONTANEOUS HUNGARIAN
}

\author{
Mária Gósy1, ${ }^{1,2}$ and Ákos Gocsál ${ }^{1,3}$ \\ ${ }^{1}$ Hungarian Academy of Sciences, ${ }^{2}$ Eötvös Loránd University, \\ and ${ }^{3}$ University of Pécs
}

\begin{abstract}
Temporal properties of words are defined by physiological, psychical, and language-specific factors. Lexical representations are assumed to be stored either in a morphologically decomposed form or in a conceptually non-decomposed form. We assumed that the duration of words with and without suffixes would refer to the route of their lexical access. Measured durations of Hungarian nouns with various lengths produced by 10 speakers in spontaneous utterances revealed significant differences, depending on the words' morphological structures. Durations of monomorphemic nouns were shorter than those of multimorphemic nouns, irrespective of the number of syllables they contained. Our interpretation is that multimorphemic words are accessed decompositionally in spontaneous speech, meaning that stem activation of the semantic representation is followed by activation of one or more suffixes. Durational differences of monomorphemic and multimorphemic words were not stable across word lengths. The number of suffixes did not influence the words' temporal patterns.
\end{abstract}

Keywords: durations, nouns, monomorphemic and multimorphemic nouns, lexical access, spontaneous utterances

DOI: https://doi.org/10.12697/jeful.2019.10.1.03

\section{Introduction}

Temporal patterns of spontaneously-produced words can be analysed by their durations measuring the whole words or considering their building morphemes. Although the number of syllables can have a decisive effect on word durations, various other factors influence the temporal patterns of words, primarily in the area of word frequency (e.g., Jescheniak and Levelt 1994, Losiewicz 1995, Fougeron and Keating 1997, Pan and Hirschberg 2000, Bell et al. 2002, Greenberg et al. 2003, Aylett and Turk, 2004, Bell et al. 2009, Gahl 2008, Jacewicz et al. 2010, Yang et al. 2013, and Mačutek et al. 2017). Word 
type (content words, function words), morphological structure, contextrelated, speaker-related factors, communication situation, topic, etc., may all change word durations - even within the same speaker's word productions. Infrequent words are assumed to be of longer duration, because highly less common lexical items take longer to access than more common forms (Howes 1967 and Milin et al. 2017). Short words are far more likely to occur within an utterance than longer words, as has been demonstrated in spoken language (e.g., Greenberg 1999 and Bell et al. 2002). Durations of regular and irregular word forms have been widely discussed in the literature (e.g., Yang 2005 and Stockall and Marantz 2006). Gahl (2008) assumes that variation of speech tempo in spontaneous speech reflects ease of lexical access. In addition, those words that are easy to retrieve are often reduced (for example, fivesyllable tulajdonképpen "really" would be pronounced as tonképpen). In sum, temporal properties of words are defined by physiological, psychical, and language-specific factors. There are phenomena influencing word durations that have been verified to exist in many languages (e.g., phrase-final lengthening and the specific reduction of syllable durations of words as the number of the syllables increases; Menzerath 1954 and Altmann 1993).

While a large number of studies have considered the factors influencing word durations, there is only a small branch of research (e.g., Losiewicz 1995 and Budd et al. 2013) focusing on such phenomena in Hungarian. Languages such as this raise a question regarding the possible differences in lexical access of multimorphemic vs. monomorphemic words. It is assumed that such words might show durational differences when containing the same number of suffixes. This question evidently pertains also to the structure and activation of the mental lexicon (e.g., Levelt 1992).

Lexical representations are assumed to be stored either in morphologically-decomposed form (e.g., Taft and Forster 1975 and Caramazza et al. 1988) or in conceptually non-decomposed form (e.g., Roelofs 1993). The theory of decomposed storage and the decompositional route of lexical access assume that morphological units are represented separately in the mental lexicon (that requires a specific route for accessing them during speech). According to this assumption, whole words are stored and activated according to their representations, while multimorphemic words (words with suffixes, affixes, inflection, or prefixes, 
as well as compounds) are accessed according to their morphemic representations. There are experiments (Burani et al. 1984, Zhang and Peng 1992, and Kazanina et al. 2008) providing evidence for the storage of lexical representations in morphologically-decomposed forms. The findings of Caramazza and colleagues (1988) showed that morphologically-nondecomposable nonwords were the easiest to process, while nonwords with partial morphological structure were processed with greater difficulty (based on reaction time and error performance analyses). Marslen-Wilson and his colleagues (1994) gave evidence for morphological decomposition of semantically transparent English word forms but not of semantically opaque forms (these latter forms behaved as monomorphemic words). Russian is a highly inflected language; Russian word recognition was confirmed using a decomposition route during the first stage of word recognition (Gor and Jackson 2013).

There are several models that have endeavoured to explain word processing in speech (both in recognition and in production). Some have assumed that the encoding of word forms involves mapping a representation of the word onto an articulatory programme). Several studies (e.g., Levelt, 1989, 1992, Roelofs 1997) support the dual-route models that hypothesise both whole word and decompositional routes (see Baayen et al. 1997). These models assume that frequency effects depend on the route used during lexical access; however, the route used depends on the word frequency. The serially ordered lemma and lexeme stages of word production have been confirmed by various experiments and by analysis of TOT-type disfluencies (e.g., Cutler 1988 and Schriefers et al. 1990).

The process of a content word activation consists of a stage of semantic and syntactic activations followed by the second stage of phonological activation (Levelt 1989 and Kazanina et al. 2008). Different levels of representations are connected to different stages of word activation (e.g., Dell 1986). Inflected English word forms were analysed using an ERP-examination (Budd et al. 2013 focusing on regular vs. irregular past-tense forms). The observed ERP responses suggested that some combinatorial processing was characteristic of regular but not of irregular past-tense formation. Irregular forms of verbs are assumed to be represented as list of exceptions in English (e.g., Yang 2005 and Stockall and Marantz 2006). 
From the perspective of lexical access, this finding seems to support the existence of the decompositional route of inflected word forms in speech production. Many studies (e.g., Marslen-Wilson et al. 1994, Sonnenstuhl et al. 1999, Rastle et al., 2004, and Stockall and Marantz 2006) provide evidence for decomposition for multimorphemic words; however, lexical access of multimorphemic words is assumed to be heavily influenced by the factor of frequency. This factor (i.e., of word stems, suffixes, and prefixes) might overwrite the assumed decompositional lexical access of some multimorphemic words, resulting in behavior that resembles whole word structure (e.g., Lignos and Gorman 2011). However, frequency is not an attribute of a word but, rather, is a result of its use by an individual. There is a decisive cohort of words that are frequent, irrespective of the individual mental lexicon of the speaker (for example, some function words or frequent content words, such as always, and, is, go, etc.), otherwise, word frequency is heavily dependent on the speaker's own language use (e.g., the word cigarette can be quite frequent for a smoker, while it is very infrequent for a nonsmoker).

The temporal interrelations of suffixed words as opposed to words without any suffix may carry information about the route of lexical access during speech planning followed by possible execution differences in time (Roelofs 1996, Vannest and Boland 1999, Onysko and Michel 2010, and Özdemir et al. 2007). Accepting this assumption, the question arises whether word durations refer to different routes of lexical access. This study focuses on the temporal patterns of words with and without suffixes with various lengths in Hungarian spontaneous speech.

Words of an agglutinating language frequently consist of a complex morphological representation the speaker must activate when speaking. Both the stem and the suffix (or suffixes) must be produced as a whole entity according to the morphological rules of the language at the same time. The routes of activation of such word constructions are subject to considerable debate. A Hungarian-suffixed noun, gyerekeitekröl ("about your children") has been used as an example to demonstrate how to access this relatively frequent multimorphemic word. We assume that all morphological units of this words should be activated separately (probably serially): the stem gyerek [jerck] "child", the suffix ei [عi] "plural", the next suffix tek [tek] "yours" and the last suffix röl [rø:l] "about". 
Three hypotheses were defined. (i) Words with suffixes would show longer durations as opposed to those of monomorphemic words. (ii) The durational differences of monomorphemic and multimorphemic words would be stable across various numbers of syllables the words consist of. (iii) We assumed that there would be no differences in word durations depending on the number of suffixes multimorphemic words contain.

\section{Methodology}

Ten young speakers ( 5 females and 5 males, with a mean age of 28 years, the standard deviation is 5 years) were selected randomly (with the exception of age and gender) from the BEA Hungarian speech database (Gósy 2012). All speakers had normal hearing. None of them had any speech defects. Speakers had either a secondary education or a university degree. All had a similar socioeconomic status; all lived in a large city.

Subjects were asked to speak about their family, life, and hobbies and to share their opinion on a specific topic raised by the interviewer (unexpectedly, according to the protocol of the database). About 2.5 hours of Hungarian spontaneous speech material was analysed; the average length of the speech material, per speaker, was 15 minutes.

Nouns with or without suffixes were selected, using the following inclusion criteria (in order to control for the variables as much as possible): (i) Stems consisted of various numbers of syllables from one to three, (ii) suffixed nouns contained one or two suffixes, (iii) all suffixes followed the stem and were the last or the last two syllables of the words, (iv) suffixes were those indicated grammatical relationships, plurals of the nouns as well as various personal and possessive suffixes, (v) all words occurred in the middle of a phrase (in order to avoid phrase-final lengthening). A total of 894 words (522 produced by females and 372 by males) were selected for analysis: 332 of them were monomorphemic and 553 of them were multimorphemic words (Table 1). 
Table 1. Distribution of monomorphemic and multimorphemic words in the material.

\begin{tabular}{lccccc}
\hline \multirow{2}{*}{$\begin{array}{l}\text { Word length } \\
\text { (number of } \\
\text { syllables) }\end{array}$} & \multicolumn{4}{c}{ Distribution of words } & Total \\
\cline { 2 - 5 } & Monomorphemic words & Multimorphemic words & $\begin{array}{c}\text { Tumber } \\
\text { num words }\end{array}$ \\
\cline { 2 - 5 } two & 173 & 52.0 & 89 & 15.8 & 262 \\
three & 99 & 29.7 & 283 & 50.4 & 382 \\
four & 61 & 18.3 & 189 & 33.8 & 250 \\
\hline Total & 333 & 100.0 & 561 & 100.0 & 894 \\
\hline
\end{tabular}

Examples: kapu "gate", iskola "school", villamos "tram", társadalom "society" vs. célja "his/her goal", lakásnak "for a flat", gyerekkel "with a child", véleményem "my opinion", balesetröl "about an accident"; életemet "my life + Acc.", szüleimmel "with my parents", üzletekböl "from shops". Individual word frequency could not be controlled reliably, but efforts were made to exclude words that were judged, subjectively, very rare by both authors (irrespective of being mono- or multimorphemic word).

The speech material was carefully hand-labeled using Praat (Boersma and Weenink 2018). Boundary location reliability was assessed at the time of segmentation using the labelers' confidence as a measure (with an agreement ratio higher than $98 \%$ ). In cases of disagreement, a third phonetician was asked to decide. The word boundaries were identified in the waveform signal and spectrogram display via continuous listening to the words according to usual acoustic-phonetic criteria for onset and offset of words (e.g., Turk and Shattuck-Hufnagel 2000). Durations of words were defined based on annotations, using a specific script that was written to obtain the values automatically.

To test statistical significance, Shapiro-Wilk, Kruskal-Wallis and Mann-Whitney U tests were used as appropriate to the data (SPSS 20.0 version). Measured durations of words were dependent variables, while the number of syllables of the stems and number of the suffixes were the independent factors. The confidence level was set at the conventional $95 \%$. 


\section{Results}

3.1. Durations of monomorphemic and multimorphemic words were analysed in the first phase of data processing, irrespective of the number of suffixes the words contained. Boxplots in Figure 1 represent the distributions of durations of two-, three- and four-syllable words, clustered according to whether they were monomorphemic or multimorphemic as they occurred in the spontaneous samples.

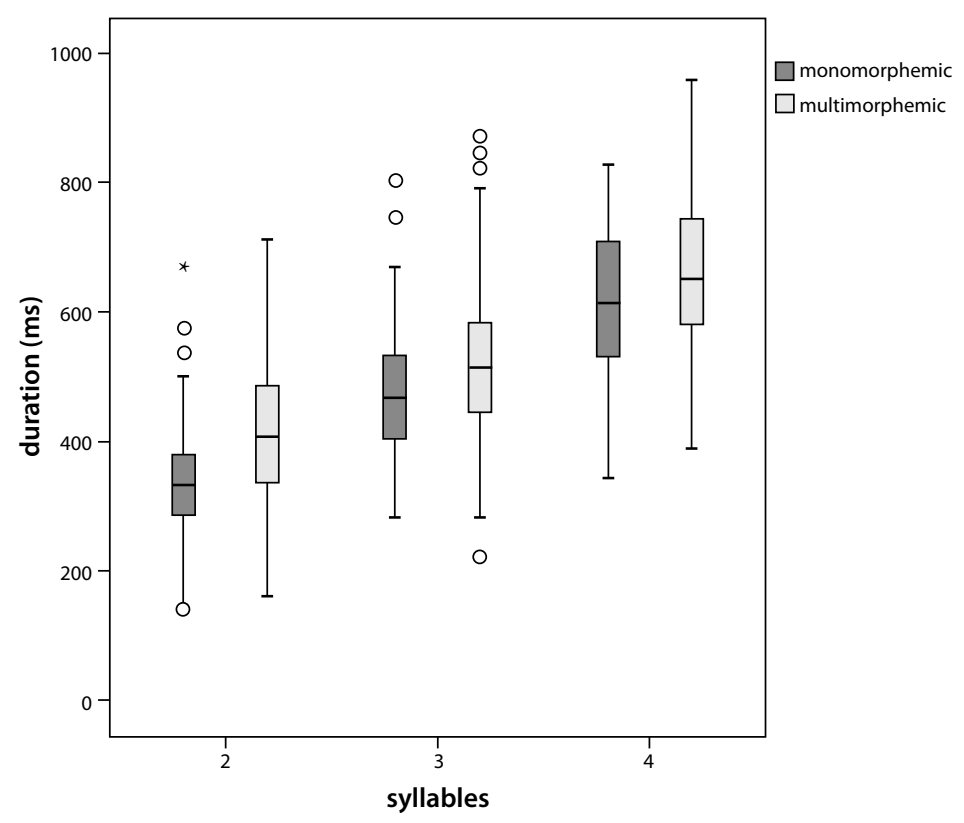

Figure 1. Durations of Hungarian monomorphemic and multimorphemic words (all nouns) according to the syllables they consist of (medians and ranges).

Since the Shapiro-Wilk test demonstrated that several of the distributions deviated from normal patterns, we administered a series of Mann-Whitney $U$ tests between the datasets of monomorphemic and multimorphemic nouns, separately for the two-, three- and foursyllable ones. This indicated $(U=4119.5, p<.001)$ that the median duration of the two-syllable multimorphemic nouns (median $=407 \mathrm{~ms}$ ) was significantly larger than that of the monomorphemic ones (median $=335 \mathrm{~ms}$ ). A second Mann-Whitney U test was performed 
on the three-syllable nouns. Again, a significant difference in word durations was found $(U=10540.5, p<.001)$ in the median durations between the multimorphemic $(515 \mathrm{~ms})$ and the monomorphemic nouns (467 ms). Durations of the four-syllable nouns also differed significantly ( $U=4380.5, p<.01)$. Median duration of the multimorphemic nouns was $650 \mathrm{~ms}$, while that of the monomorphemic nouns was $614 \mathrm{~ms}$.

The durations of both the monomorphemic and multimorphemic words showed increases as the number of the building syllables increased: three-syllable monomorphemic words were longer than two-syllable ones by $108 \mathrm{~ms}$ (on average), while four-syllable monomorphemic words were longer than three-syllable ones by $135 \mathrm{~ms}$ (on average). Similar increases could be found in the case of multimorphemic words; however, the increase was larger in their cases than those found in monomorphemic words (132 ms and $147 \mathrm{~ms}$, on average, respectively). Our data supported that syllables of words are shorter as their number increases in a word, resulting in a specific linear increase of durations of words with various lengths (cf. Cramer 2005).

Comparing the median value differences across words with various syllables, we found that the durational difference between monomorphemic and multimorphemic nouns was the largest in the case of two-syllable words $(72 \mathrm{~ms})$, less in the case of three-syllable words $(48 \mathrm{~ms})$, and shortest in the case of four-syllable words (36 ms).

3.2. In the second phase of analysis, we wanted to learn whether the number of suffixes influenced word duration. In Hungarian, a threesyllable noun can be structured in one of three ways: (i) there are monomorphemic nouns, (ii) a multimorphemic noun can have a two-syllable stem and a one-syllable suffix, and (iii) a multimorphemic noun can have a one-syllable stem and two one-syllable suffixes. Our analysis focused on three-syllable word durations depending on their three possible structures. Table 2 shows the number of nouns belonging to the above-described word structural groups with examples. 
Table 2. Distribution of three-syllable words with different syllables of stems and one or two suffixes (suffixes are in bold).

\begin{tabular}{lcc}
\hline \multicolumn{3}{c}{ Distribution of three-syllable words } \\
\hline Types & Item & Percent \\
\hline monomorphemic, e.g., pillanat "minute" & 99 & 25.9 \\
$\begin{array}{l}\text { two-syllable stem + a one-syllable suffix, e.g., } \\
\text { világban "in /the/ world" }\end{array}$ & 228 & 59.6 \\
$\begin{array}{l}\text { one-syllable stem + 2 one-syllable suffixes, e.g., } \\
\text { padodon "on your bench" }\end{array}$ & 55 & 14.5 \\
\hline Total & 382 & 100.0 \\
\hline
\end{tabular}

A Kruskal-Wallis test was conducted to examine the differences in the durations of three-syllable nouns depending on the number of suffixes. Results showed that there was at least one pair among the groups with a significant difference $\left(\chi^{2}(2)=14.777, p=.001\right)$. DunnBonferroni tests were carried out to obtain statistical information on the possible differences of the pairs of groups. The post hoc tests provided evidence that the durations of the three-syllable monomorphemic nouns (median $=467 \mathrm{~ms})$ were significantly shorter $(p=.003)$ than those of the nouns with two-syllable stems and one suffix (median $=514 \mathrm{~ms}$ ), and were also significantly shorter $(p=.002)$ than the durations of the nouns with one-syllable stems and two suffixes (median $=548 \mathrm{~ms}$ ). Word durations consisting of one or two suffixes did not differ significantly. The boxplots in Figure 2 illustrate the distribution of the word duration data. 


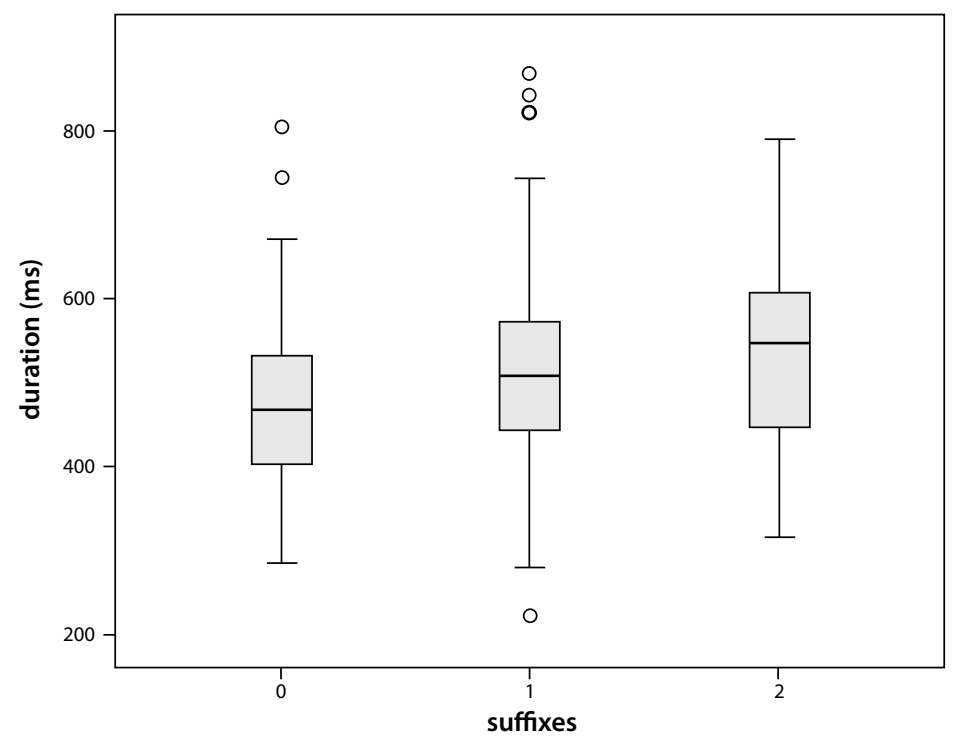

Figure 2. Boxplots represent durations of three-syllable nouns with 0,1 , and 2 suffixes (medians and ranges).

The same analysis was performed concerning the word durations of the four-syllable nouns. The possible word types and the number and percent of the words belonging to the different groups with examples are summarised in Table 3. The boxplots in Figure 3 show the distribution of word durations belonging to different structural groups.

Table 3. Distribution of four-syllable words with different syllables of stems and one or two suffixes (suffixes are in bold).

Distribution of four-syllable words

\begin{tabular}{lcc}
\hline Four-syllable word types & Item & Percent \\
\hline monomorphemic, e.g., hozzáállás "attitude" & 61 & 24.4 \\
$\begin{array}{l}\text { three-syllable stem + a one-syllable suffix, e.g., } \\
\text { funkcióhoz "for a function" }\end{array}$ & 132 & 52.8 \\
$\begin{array}{l}\text { two-syllable stem + 2 one-syllable suffixes, e.g., } \\
\text { családokban "in families" }\end{array}$ & 57 & 22.8 \\
\hline Total & 250 & 100.0 \\
\hline
\end{tabular}




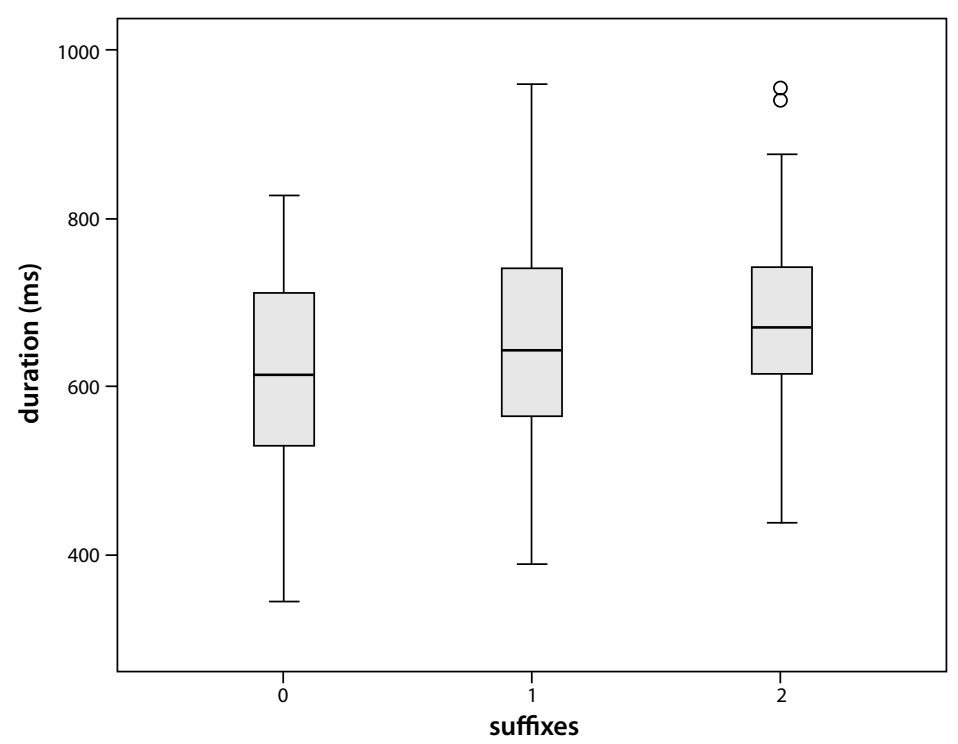

Figure 3. Boxplots represent durations of four-syllable nouns with 0,1 , and 2 suffixes (medians and ranges).

For statistical analysis, a Kruskal-Wallis test was used that provided evidence for a difference in word duration between at least one pair of groups $\left(\chi^{2}(2)=8.932, p=.011\right)$. Dunn-Bonferroni post hoc tests were carried out for the three pairs of datasets, and revealed that monomorphemic words are significantly shorter (median $=614 \mathrm{~ms}$ ) than both structural word types either with a three-syllable stem and one suffix, or a two-syllable stem and two suffixes (medians $=643 \mathrm{~ms}$ and $670 \mathrm{~ms}$, respectively, and $p=.028$ and .004 , respectively). The durations of words with one or two suffixes did not differ significantly.

\section{Conclusions}

The temporal properties of words are both physiologically and psychically defined while also language-specific and psycholinguistic factors influence their objective durations. One of the language userelated factors is lexical access in connection with storage in the mental lexicon. In Hungarian, stems can consist of three or more syllables as a consequence of the agglutinative character of the language, and they 
can have one or more suffixes occurring after the stem in fluent speech. Words can be accessed in speech production either decompositionally. according to various morphemes of which the word consists or, alternatively, as a whole entity in cases where the word contains only one morpheme. We found that nouns with one or more suffixes were produced more slowly than those without any suffix. The measured data showed significant differences in durations between monomorphemic and multimorphemic nouns irrespective of their total number of syllables.

Our first assumption, that words with suffixes would show longer durations in comparison to those of monomorphemic words, were confirmed. Suffixed words had significantly longer durations than those without any suffix, irrespective of the number of suffixes. Accepting the view that word durations refer to the route of their lexical access, we can claim that words with and without suffixes have different routes of lexical access. Since special care was taken to avoid (i) pauses following the selected words and (ii) words of generally unusual meaning, the difference in the durations between the monomorphemic and multimorphemic words can be explained primarily by differences in their lexical access. In addition, phonological rules and their encoding across morpheme boundaries have to be taken into account as processes that increase word production complexity. The next example of the suffixed noun lakás+ban [loka:zbon] "in /a/ flat" contains the emergence of a voicing rule at the boundary of the stem and the suffix resulting in the voicing counterpart ([3]) of the voiceless consonant ([J]). Phonological encoding might also contribute to an increase of duration during lexical access. Our interpretation is that multimorphemic words are accessed decompositionally in spontaneous speech, meaning that stem activation of the semantic representation is followed by activation of one or more suffixes in a serial or almost serial order. This process requires longer time during lexical access, resulting in longer word durations.

There are monomorphemic words whose durations are longer than those of multimorphemic words, and vice versa, multimorphemic words can be produced that are shorter than monomorphemic ones with the same number of syllables. These data are reflected in overlaps between structurally different word groups (see Figure 1). There are various explanations for these facts: different types of syllables 
across word stems and suffixes, speakers' various articulation tempi, speaker-specific frequency of words, semantic and syntactic context, 'old' and 'new' information behind the word production, occurrence in the phrase, etc. Various factors defining the duration of a given word in a specific context in spontaneous utterances seem to be undefinable without further delineation.

We assumed that the durational differences of monomorphemic and multimorphemic words would be stable across various numbers of syllables comprising the word. The data did not confirm this hypothesis. The durational differences between the structural types of nouns showed a gradual decrease as the word length (i.e., the number of syllables) increased. The possible explanation for this decrease lies in the relatively large durational differences of words with various lengths. However, durations of multimorphemic words increased to a greater extent than monomorphemic words did with increasing word length, particularly between two- and three-syllable words. This fact, again, seems to support the different routes of lexical access of words with and without suffixes.

Finally, we assumed that there would be no differences in word duration depending on the number of suffixes multimorphemic words contained. The data confirmed this hypothesis. The number of the suffixes multimorphemic words contained turned out to be irrelevant. It seems that the number of the suffixes does not influence significantly the durations of words. The median differences of noun durations between 1 and 2 suffixes was $34 \mathrm{~ms}$ in the case of the three-syllable nouns, while it was $27 \mathrm{~ms}$ in the case of the four-syllable nouns. The ranges were large in both cases (see Figures 2 and 3). We think that this finding can be explained by various phonetic and phonological patterns of suffixes, on the one hand, and the suffixation strategy of the speakers, on the other. For example, the duration of two words with the same number of syllables can be shorter with two suffixes and longer

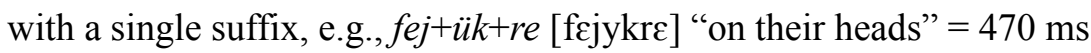
vs. bátyám+nak [ba:ca:mnok] "for my brother" $=580 \mathrm{~ms}$. In addition, we assume that, after accessing the first suffix, the second one might be easier to activate because the morphological encoding strategy is already in progress. 
There are limitations to this study. We measured the durations of nouns; however, we are convinced that verbs would behave very similarly. We could not control properly the speakers' own mental lexicon, lexical access strategies, or frequency of words of the users (though there is some doubt as to whether these factors can be controlled in a methodologically reasonable way). Despite these difficulties, we think that our study is a good step forward in understanding the routes of lexical access in spontaneous speech, at least in the case of nouns.

\section{Addresses:}

Mária Gósy

Research Institute for Linguistics, Department of Phonetics

Hungarian Academy of Sciences

Budapest

Benczúr u. 33.

H-1068

Hungary

E-mail: gosy.maria@nytud.mta.hu

Ákos Gocsál
University of Pécs

Faculty of Music and Visual Arts, Institute of Music

Pécs

Zsolnay V. u. 16.

H-7622

Hungary

E-mail: gocsal.akos@pte.hu

\section{References}

Altmann, Gabriel (1993) "Science and linguistics". In Reinchard Köhler and Burghard B. Rieger, eds. Contributions to quantitative linguistics, 3-10. Dordrecht: Kluwer. Aylett, Matthew and Alice Turk (2004) "The smooth signal redundancy hypothesis: a functional explanation for relationships between redundancy, prosodic prominence, and duration in spontaneous speech". Language and Speech 47, 31-56. https://doi.org/10.1177/00238309040470010201

Baayen, Harald R., Ton Dijkstra, and Robert Schreuder (1997) "Singulars and plurals in Dutch: evidence for a parallel dual-route model". Journal of Memory and Language 37, 94-117. https://doi.org/10.1006/jmla.1997.2509 
Bell, Alan, Jason M. Brenier, Michelle Gregory, Cynthia Girand, and Dan Jurafsky (2009) "Predictability effects on durations of content and function words in conversational English". Journal of Memory and Language 60, 1, 92-111. https://doi.org/10.1016/j.jml.2008.06.003

Bell, Alan, Michelle L. Gregory, Jason M. Brenier, Dan Jurafsky, Ayako Ikeno, and Cynthia Griand (2002) "Which predictability measures affect content word durations?". Proceedings of the ISCA workshop on pronunciation modeling and lexicon adaptation for spoken language technology (PMLA-2002), 1-5.

Boersma, Paul and David Weenink (2018). Praat: doing phonetics by computer [Computer program]. Version 5.4.1. Available online at $<$ http://www.praat.org/>. Accessed on 16.10.2018.

Budd, Mary-Jane, Slke Paulmann, Christofer Barry, and Harald Clahsen (2013) "Brain potentials during language production in children and adults: an ERP study of the English past tense". Brain and Language 127, 345-355.

https://doi.org/10.1016/j.bandl.2012.12.010

Burani, Cristina, Dario Salmaso, and Alfonso Caramazza (1984) "Morphological structure and lexical access". Visible Language 18, 348-358.

Caramazza, Alfonso, Alessandro Laudanna, and Cristina Romani (1988). "Lexical access and inflectional morphology". Cognition 28, 3, 297-332.

Cramer, Irene M. (2005) “Das Menzerathsche Gesetz”. In Reinchard Köhler, Gabriel Altmann, and Rajmund G. Piotrowski, eds. Quantitative linguistics: an international handbook, 659-688. Berlin and New York: De Gruyter.

Cutler, Anne (1988) "The perfect speech error”. In Larry M. Hyman and Charles N. Li, eds. Language, speech and mind: studies in honour of Victoria A. Fromkin, 209-223. London: Routledge.

Dell, Gary (1986) “A spreading activation theory of retrieval in language production". Psychological Review 93, 283-321.

Fougeron, Cecile and Patricia A. Keating (1997) "Articulatory strengthening at edges of prosodic domains". The Journal of the Acoustical Society of America 101, 6, 3728-3740. https://doi.org/10.1121/1.418332

Gahl, Susanne (2008) "Time and thyme are not homophones: word durations in spontaneous speech." Language 84, 474-496.

Gósy, Mária (2012) "BEA - A multifunctional Hungarian spoken language database". The Phonetician 105/106, 50-61. Available online at $<$ http://www.isphs.org/Phonetician/Phonetician_105_106.pdf $>$ Accessed on 21.06.2019.

Gor, Kira and Scott Jackson (2013) "Morphological decomposition and lexical access in a native and second language: a nesting doll effect". Language and Cognitive Processes 28, 7, 1065-1091. https://doi.org/10.1080/01690965.2013.776696

Greenberg, Steven (1999) "Speaking in shorthand: a syllable-centric perspective for understanding pronunciation variation". Speech Communication 29, 159-176.

Greenberg, Steven, Hannah Carvey, Leah Hitchcock, and Shuangyu Chang (2003) "Temporal properties of spontaneous speech-a syllable-centric perspective". Journal of Phonetics 31, 465-485. https://doi.org/10.1016/j.wocn.2003.09.005 
Howes, D. H. (1967) "Hypotheses concerning the functions of the language mechanisms". In Kurt Salzinger and Suzanne Salzinger, eds. Research in verbal behaviour and some neuropsychological implications, 429-455. New York: Academic Press.

Jacewicz, Eva, Robert A. Fox, and Lai Wei (2010) "Between-speaker and withinspeaker variation in speech tempo of American English". Journal of the Acoustical Society of America 128, 2, 839-850. https://doi.org/10.1121/1.3459842

Jescheniak, Jörg D. and Willem J. M. Levelt (1994) "Word frequency effects in speech production: retrieval of syntactic information and of phonological form". Journal of Experimental Psychology: Learning, Memory and Cognition 20, 824-843. https://doi.org/10.1037/0278-7393.20.4.824

Kazanina, Nina, Galina Dukova-Zheleva,Viktor Kharlamov, and Keren Tonciulescu (2008) "Decomposition into multiple morphemes during lexical access: a masked priming study of Russian nouns". Journal of Language and Cognitive Processes 23, 6, 800-823. https://doi.org/10.1080/01690960701799635

Levelt, Willem J. M. (1989) Speaking: from intention to articulation. Cambridge, MA: MIT Press.

Levelt, Willem J. M. (1992) “Accessing words in speech production: stages, processes and representations". Cognition 42, 1-22. https://doi.org/10.1016/0010-0277(92)90038-J

Lignos, Constantine and Kyle Gorman (2012) "Revisiting frequency and storage in morphological processing". Proceedings of Chicago Linguistic Society 48, 447-461.

Losiewicz, Beth L. (1995) "Word frequency effects on the acoustic duration of morphemes". Journal of the Acoustical Society of America 97, 5, 32-43. https://doi.org/10.1121/1.411745

Mačutek, Ján, Radek Čech, and Jiří Milička, (201) "Menzerath-Altmann Law in syntactic dependency structure". Proceedings of the Fourth International Conference on Dependency Linguistics (Depling 2017), 100-107.

Marslen-Wilson, William, Lorraine K. Tyler, Rachelle Waksler, and Lianne Older (1994) "Morphology and meaning in the English mental lexicon". Psychological Review 101, 1, 3-33. Available online at <https://csl.psychol.cam.ac.uk/publications/ pdf/94_Marslen-Wilson_PsychRev.pdf $>$ Accessed on 21.06.2019.

Menzerath, Paul (1954) Die Architektonik des deutschen Wortschatzes. Bonn: Dümler.

Milin, Petar, Beth L. Feldman, and Eva Smolka (2017) "Models of lexical access and morphological processing". In Eva M. Fernández and Helen Smith Cairns, eds. The handbook of psycholinguistics, 240-268. Hoboken, NJ: Wiley. https://doi.org/10.1002/9781118829516.ch11

Onysko, Alexander and Sascha Michel, eds. (2010) Cognitive perspectives on word formation. Berlin and New York: De Gruyter, Mouton. https://doi.org/10.1515/9783110223606

Özdemir, Rebecca, Ardi Roelofs, and Willem J. M. Levelt (2007) "Perceptual uniqueness point effects in monitoring internal speech". Cognition 105, 2, 457-465. https://doi.org/10.1016/j.cognition.2006.10.006 
Pan, Shimei and Julia Hirschberg (2000) "Modeling local context for pitch accent prediction". ACL '00 Proceedings of the 38th Annual Meeting on Association for Computational Linguistics, 233-240. https://doi.org/10.3115/1075218.1075248

Rastle, Kathleen, Matthew H. Davis, and Boris New (2004) "The broth in my brother's brothel: morpho-orthographic segmentation in visual word recognition". Psychonomic Bulletin and Review 11, 6, 1090-1098.

https://doi.org/10.3758/BF03196742

Roelofs, Ardi (1993) "Testing a non-decompositional theory of lemma retrieval in speaking: retrieval of verbs". Cognition 47, 59-87. https://doi.org/10.1016/0010-0277(93)90062-Z

Roelofs, Ardi (1996). "Serial order in planning the production of successive morphemes of a word". Journal of Memory and Language 35, 854-876.

Roelofs, Ardi (1997) "The WEAVER model of word-form encoding in speech production". Cognition 64, 249-284. https://doi.org/10.1016/S0010-0277(97)00027-9

Schriefers, Herbert, Antje S. Meyer, and Willem J. M. Levelt (1990) "Exploring the time course of lexical access in language production: picture-word interference studies". Journal of Memory and Language 29, 86-102.

https://doi.org/10.1016/0749-596X(90)90011-N

Sonnenstuhl, Ingrid, Sonja Eisenbeiss, and Harald Clahsen (1999) "Morphological priming in the German mental lexicon". Cognition 72, 3, 203-236.

https://dx.doi.org/10.1016/S0010-0277(99)00033-5

Stockall, Linnaea and Alec Marantz (2006) "A single route, full decomposition model of morphological complexity: MEG evidence". The Mental Lexicon 1, 1, 85-123. https://doi.org/10.1075/ml.1.1.07sto

Taft, Marcus and Kenneth I. Forster (1975) "Lexical storage and retrieval of prefixed words". Journal of Verbal Learning and Verbal Behavior 14, 638-647. https://doi.org/10.1016/S0022-5371(75)80051-X

Turk, Alice E. and Stefanie Shattuck-Hufnagel (2000) "Word-boundary-related duration patterns in English". Journal of Phonetics 28, 4, 397-440.

https://doi.org/10.1006/jpho.2000.0123

Vannest, Jennifer and Julie E. Boland (1999) "Lexical morphology and lexical access". Brain and Language 68, 1-2, 324-332. http://dx.doi.org/10.1006/brln.1999.2114

Yang, Charles (2005) “On productivity”. Linguistic Variation Yearbook 5, 1, 265-302. https://doi.org/10.1075/livy.5.09yan

Yang, Zhaojun, Vikram Ramanarayanan, Dani Byrd, and Shrikanth Narayanan (2013) "The effect of word frequency and lexical class on articulatory-acoustic coupling". Proceedings of Interspeech 2013, 973-977. Available online at $<$ http://vikramr.com/pubs/LexicalClassEffects_ArticulatoryAcousticCoupling.pdf> Accessed on 21.06.2019.

Zhang, Biyin and Danling Peng (1992) "Decomposed storage in the Chinese lexicon". In Hsuan Chih Chen and Ovid J. L. Tzeng, eds. Language processing in Chinese, 131-149. (Advances in Psychology, 90.) Amsterdam, London, New York, and Tokyo: North-Holland. 
Kokkuvõte. Mária Gósy ja Ákos Gocsál: Sufiksiga ja sufiksita sõnade ajaline struktuur spontaanses ungari keeles. Sõnade ajalised omadused sõltuvad füsioloogilistest, psühholoogilistest ja keelespetsiifilistest teguritest. Eelduste kohaselt on sõnad mentaalses leksikonis representeeritud kas morfeemideks analüüsituna või tervikmõistena. Uurimuses lähtuti eeldusest, et sufiksiga ja sufiksita sõnade kestus viitab sellele, kuidas juurdepääs neile toimub. Mõõdeti kümne kõneleja spontaansetes lausungites produtseeritud eri pikkusega ungari nimisõnade kestust. Ilmnes, et kestus sõltus oluliselt sõna morfoloogilisest ülesehitusest. Tüvisõnade kestus oli tuletiste omast lühem, sõltumata silpide arvust sõnas. Järelduseks saadi, et juurdepääs tuletistele toimub spontaanses kõnes osade kaupa: tüve semantilise representatsiooni aktiveerimisele järgneb sufiksi või sufiksite aktiveerimine. Tüvisõnade ja tuletiste kestuserinevused olid eri pikkusega sõnade puhul erinevad. Sufiksite arv sõna ajalist struktuuri ei mõjutanud.

Märksõnad: kestus, nimisõnad, tüvisõnad ja tuletised, leksikaalne juurdepääs, spontaansed lausungid 